\title{
SUAPE EM CONSTRUÇÃO, PEÕES EM LUTA: o novo desenvolvimento e os conflitos do trabalho' ${ }^{1}$
}

\author{
Roberto Véras de Oliveira*
}

\begin{abstract}
Este artigo discute, pela ótica do trabalho e de seus conflitos, a emergência de uma nova agenda de desenvolvimento no Brasil. Tem como foco as revoltas e greves dos trabalhadores que atuam na construção de dois dos principais empreendimentos do Complexo Industrial Portuário de Suape, a Refinaria Abreu e Lima e a Petroquímica Suape, durante os anos de 2011 e 2012. Esta abordagem pretende apreender os processos desencadeados pelos conflitos, mediações e negociações e o que tem estado em disputa, com as demandas dos trabalhadores e os discursos e práticas governamentais, empresariais e sindicais. Perguntamo-nos se essas mobilizações, além de trazerem ganhos imediatos para os trabalhadores, têm permitido que estes se façam reconhecer como legítimos portadores de demandas sociais. E em que medida tais demandas vêm sendo não só objeto de denúncia pública, mas, também, um modo de problematizar os termos que dão sustentação ao novo discurso desenvolvimentista.

Palavras-chave: Desenvolvimento. Trabalho. Sindicalismo. Construção civil. Suape.
\end{abstract}

\section{INTRODUÇÃO}

Este artigo discute, pela ótica do trabalho e de seus conflitos, a emergência de uma nova agenda de desenvolvimento no Brasil. Tem como foco as revoltas e greves dos trabalhadores que atuam na construção de dois dos principais empreendimentos do Complexo Industrial Portuário de Suape, a Refinaria Abreu e Lima e a Petroquímica Suape, durante os anos de 2011 e 2012. Busca problematizar, a partir deste caso, a reedição de uma construção prático discursiva de teor desenvolvimentista no País.

\footnotetext{
* Doutor em Sociologia. Professor do Departamento de Ciências Sociais da Universidade Federal da Paraíba UFPB - e membro do Programa de Pós-Graduação em Sociologia da UFPB - PPGS-e do Programa de Pós-Graduação em Ciências Sociais da Universidade Federal de Campina Grande - PPGCS/UFCG.

Av. Washington Luis, 268, apto 201, Bessa. Cep: 58035-340. João Pessoa-Paraíba-Brasil. roberto.veras.2002@gmail.com

${ }^{1}$ Este artigo resulta de reflexões realizadas a partir do projeto "O novo desenvolvimentismo no Brasil visto a partir de suas implicações sociais no Nordeste", desenvolvido no âmbito do Laboratório de Estudos e Pesquisas sobre Políticas Públicas e Trabalho - LAEPT/UFPB em parceria com a Fundação Joaquim Nabuco - FUNDA] e o Observatório PE - UFPE. Ao mesmo tempo em que agradeço as contribuições dos colegas, assumo toda responsabilidade pelo seu conteúdo. Agradeço, ainda, as importantes contribuições dos pareceristas anônimos.
}

O Complexo Industrial Portuário Governador Eraldo Gueiros - Suape, ou CIPS, está situado na Região Metropolitana de Recife - RMR, ${ }^{2}$ Litoral Sul de Pernambuco, nos municípios de Ipojuca e Cabo de Santo Agostinho, abrangendo uma área de 13,4 mil hectares. A partir da primeira edição do Programa de Aceleração do Crescimento - PAC, em 2007, se constituiu em um dos maiores polos de investimentos do país.

Pernambuco vive um boom econômico, após um período de declínio. A economia regional esteve, por décadas, sob forte impacto dos incentivos fiscais da Superintendência do Desenvolvimento do Nordeste - SUDENE. De 1963 a 1969, o estado foi o principal beneficiário dessa política, recebendo 36,9\% dos incentivos (seguido da Bahia, com 32,8\%). Tal participação caiu, entre 1970 a 1974, para 25,7\% e, de 1975 a 1984, para 16,6\%. Acompanhando a evolução dos investimentos incentivados pela Sudene, o PIB estadual cresceu

${ }^{2} \mathrm{~A}$ RMR inclui os municípios de Abreu e Lima, Araçoiaba, Cabo de Santo Agostinho, Camaragibe, Igarassu, Ipojuca, Itamaracá, Itapissuma, Jaboatão dos Guararapes, Moreno, Olinda, Paulista, Recife e São Lourenço da Mata. 
$10,6 \%$ ao ano de 1970 a 1975, 6,6\% de 1975 a 1980 e 2,4\% de 1980 a 1985, invertendo sua relação com o PIB regional (com médias anuais, respectivamente, de 10,2\%, 7,2\% e 4,4\%). Após alguma recuperação no final dos anos 1980, Pernambuco cresceu, na década de 1990, com médias anuais de 2,0\% e o Nordeste, com 3,0\%. Concorreu para tal evolução a exclusão do estado do II Plano Nacional de Desenvolvimento - PND, lançado em 1975, o qual previu investimentos para a Bahia (Pólo Petroquímico de Camaçari), Alagoas e Sergipe (Complexo Cloroquímico), Maranhão (Pólo Minerometalúrgico) (Lima e Katz, 1993).

A proposta do Porto de Suape surgiu nos anos 1960, inspirando-se nos complexos industrial-portuários de Marseille-Fos, na França, e de Kashima, no Japão (Suape/Governo Pernambuco, 2010). ${ }^{3}$ Ainda durante os procedimentos preliminares, em 1975 foi publicado um manifesto assinado por intelectuais pernambucanos, liderados pelo economista Clóvis Cavalcanti, em um protesto (sobretudo de teor ambiental) à construção do porto, ${ }^{4}$ evidenciando a relevância pública que o projeto já havia adquirido, assim como o seu caráter controverso (Cavalcanti, 2008). O processo, no entanto, seguiu. Em 1977, foi realizada a desapropriação da área e foram iniciadas as obras de infraestrutura (porto, sistema viário, abastecimento d'água, energia elétrica e telecomunicações). Em 1978, foi formalizada a criação da empresa pública estadual "com a finalidade de administrar a implantação do distrito industrial, o desenvolvimento das obras e a exploração das atividades portuárias" (Suape/Governo Pernambuco, 2010). Quanto às comunidades locais, estabeleceu-se um misto de esperança e medo, conforme apurou o relatório que deu suporte ao Plano Diretor de preservação e revitalização do Cabo de Santo Agostinho, Vila de

3 A ideia originou-se de um estudo realizado pelo Padre francês Louis Lebret, para a Comissão de Desenvolvimento Econômico de Pernambuco, o qual foi publicado em Lebret (1955). Isso sugere o quanto o projeto Suape, desde suas mais remotas origens, se encontra associado ao pensamento e às políticas desenvolvimentistas.

${ }^{4}$ O "Manifesto Suape" foi publicado no semanário Jornal da Cidade (ano II, n. 24, 6, 12/4/75). Encontra-se disponível em: http://cloviscavalcanti.blogspot.com.br/p/manifesto-suape.html (Acesso em 25/06/2012).
Nazareth, povoados de Baibu e Suape, realizado por Sena Caldas \& Polito Arquitetos Associados Ltda (1980, apud Rocha, 2000).

O Complexo de Suape começou a funcionar com a incorporação, em 1986, da BR Distribuidora, Shell, Texaco e Esso, oriundas do Porto do Recife. Em 2005, foi anunciado o projeto da Refinaria Abreu e Lima, produto, inicialmente, de uma negociação entre a Petrobras e a Petróleo de Venezuela S.A. - PDVSA. Conforme Santos (2012), até esse momento, "Suape se caracterizaria por investimentos no porto e na instalação de empresas de médio porte, com baixa complexidade tecnológica, pouca exigência de qualificação profissional e limitada capacidade de irradiação na economia regional”. A partir de 2007, com o Programa de Aceleração do Crescimento - PAC, o Complexo passou a atrair grandes investimentos públicos e privados, convertendo-se, desde então, com seu entorno, em um gigantesco "canteiro de obras". Os investimentos públicos no CIPS passaram de R\$ 155 milhões (entre 1995 e 1998) para R\$ 136 milhões (1999 a 2002) e R \$ 147,6 milhões (2003 a 2006); enquanto, entre 2007 e 2010, pularam para R\$ 1,46 bilhões. Quanto aos investimentos privados, totalizaram US\$2,2 bilhões até 2006; sendo que, de 2007 a 2010, reuniram US\$ 17 bilhões (Suape/Governo Pernambuco, 2010).

O Complexo, na atualidade, compreende mais de 100 empresas instaladas e dezenas de outras em fase de instalação. Alguns destaques: Refinaria Abreu e Lima e Petroquímica Suape (Petrobrás); Estaleiro Atlântico Sul - EAS; Energética Suape (termelétrica); Impsa Wind Power (fabricação de geradores eólicos); Bunge (refinaria de óleos vegetais, fabricação de margarinas e moinho de trigo); Tecon Suape (logística do porto). Oficialmente, estima-se em 25 mil o número de empregos diretos projetados para as empresas instaladas e em instalação (Suape/ Governo Pernambuco, 2010). A Refinaria representa, de longe, o maior investimento, estimado em US\$ 13 bilhões. A previsão oficial é que gerará 1,5 mil empregos diretos e algo em torno de $130 \mathrm{mil}$ indiretos. As obras de construção tiveram início em 2007, com previsão inicial de conclusão para 
2011, sendo adiada para 2012 e, depois, para 2013. O número de trabalhadores envolvidos na construção da Refinaria e da Petroquímica foi avaliado em cerca de 50 mil no final de 2012 (Santos, 2012).

Para Moutinho et al (2011), o bom momento da economia pernambucana resultou, sobretudo, de definições estratégicas de desenvolvimento nacional e regional, materializadas nos grandes investimentos do PAC, nos quais se destacam, além de Suape: a Ferrovia Nova Transnordestina, a Transposição do Rio São Francisco, o Pólo Farmacoquímico. Acrescente-se a esses: a fábrica da Fiat, a Cidade da Copa, entre outros. ${ }^{5}$ Com isso, o projeto Suape adquiriu peso nas agendas do Governo do Estado e dos governos municipais do entorno, ganhou posição de destaque na mídia local e no imaginário dos pernambucanos. No discurso de Eduardo Campos, o tom é sempre eufórico e o conteúdo, desenvolvimentista:

Pernambuco vive um momento muito especial em sua economia. Investimentos públicos e privados estão tirando do papel empreendimentos importantes, que transformam a sociedade e a vida dos pernambucanos de uma maneira nunca vista em sua história [...] Nesse contexto, Pernambuco, que é destaque no País, centraliza as atenções dos investidores, sendo Suape a mola propulsora desse desenvolvimento (Suape/Governo Pernambuco, 2010).

As críticas às consequências ambientais $\mathrm{e}$ sociais do projeto estiveram presentes desde as suas origens (Cavalcanti, 2008). Contudo, o empreendimento seguiu. Especialmente, ganhou maior legitimidade e força quando da retomada de uma agenda desenvolvimentista no país e na região. De algum modo, se estabeleceu incorporando elementos da crítica, em um esforço de justificação. ${ }^{6}$ Foi

${ }^{5}$ As conexões entre a trajetória histórica do Complexo Suape e as economias estadual, regional e nacional, sobretudo no que se refere ao seu momento atual, com os investimentos do PAC em Pernambuco, no Nordeste e no país, assim como com os investimentos públicos, privados e mistos, impulsionados a partir de então, não podem ser menosprezados. Trata-se da atualização da inserção do Nordeste e de Pernambuco na divisão regional do trabalho, que se consumou com forte base na implementação do projeto da Sudene (Oliveira, 1981).

${ }^{6}$ Usamos o termo em um sentido próximo ao atribuído por Boltanski e Chiapello (2009, p. 52-53): "Já lembramos a importância que tem, para o capitalismo, a possibilidade de apoiar-se num aparato justificativo adaptado assim que o novo Plano Diretor Suape 2030, publicado em 2011, buscou compatibilizar suas razões econômicas (portuário-industriais) com demandas ambientais, culturais, sociais. Em destaque, incorporou uma ampliação da Zona de Proteção Ecológica, de 48\% para 59\% da área total (Folha de Pernambuco, 30/09/2011). O adjetivo "sustentável” ganhou importância crescente nos discursos dos agentes estratégicos de Suape. Em maio de 2008, empresários e políticos se reuniram na sede da Federação das Indústrias de Pernambuco para tratar do tema do "Desenvolvimento Sustentável do Território Estratégico de Suape". Na ocasião, o BNDES apresentou um projeto para a região, prevendo apoio a ações em: controle urbanoambiental; tratamento de resíduos sólidos; articulação de arranjos produtivos locais; sistema viário; transporte público; educação; qualificação profissional; preservação do patrimônio histórico, turístico e cultural (JC, ${ }^{7}$ 17/05/2008). Entretanto, o convênio só foi firmado em setembro de 2010, com a denominação de Programa Especial de Controle Urbano-Ambiental no Território Estratégico de Suape, com recursos não reembolsáveis de R $\$ 10,9$ milhões. O representante do BNDES em Pernambuco, Paulo Guimarães, em declaração ao JC (12/08/2011), deixou escapar um elemento de compensação nessa iniciativa: "temos uma grande preocupação com o desenvolvimento social do território, porque o banco financiou os principais grandes empreendimentos instalados em Suape". Daí derivou o Programa Suape Sustentável, lançado em 2011, envolvendo os gestores do CIPS, oito secretarias de estado, prefeituras, as empresas instaladas em Suape, o BNDES, o Banco do Nordeste, ente outros. Declarou-se, com o referido Pro-

às formas concretas assumidas pela acumulação do capital em determinada época, o que significa que o espírito do capitalismo incorpora outros esquemas, que não os herdados da teoria econômica (...) Mas o capitalismo não pode encontrar em si mesmo nenhum recurso para fundamentar motivos de engajamento e, em especial, para formular argumentos orientados para a exigência de justiça (...) A justificação do capitalismo, portanto, supõe referência a construtos de outra ordem, da qual derivam exigências completamente diferentes daquelas impostas pela busca do lucro".

7 Utilizamos as siglas “JC", para Jornal do Commercio, e "DP”, para Diário de Pernambuco. 
grama, o propósito de transformar o Complexo Suape e seu Território Estratégico em um modelo de "desenvolvimento sustentável”, "equilibrando o crescimento econômico, a inclusão social e a preservação do meio ambiente" (http:// www.suape.pe.gov.br).

Um esforço de justificação das atuais políticas de desenvolvimento parece estabelecido no construto discursivo dos agentes estratégicos de Suape, o que não tem ocorrido senão sob uma contraditória composição entre racionalidades de teor econômico, social e ambiental. Quanto ao lugar do trabalho no novo discurso desenvolvimentista em Pernambuco e Suape, ao que tudo indica, tem se fixado em dois pontos principais: na capacidade dos empreendimentos gerarem empregos e no crescente desafio de qualificar e incorporar os trabalhadores pernambucanos em mão de obra apta a ocupar os agora exigentes postos de trabalho. Uma declaração de Eduardo Campos ao JC (01/01/2012), no início do seu segundo mandato, é ilustrativa quanto a isso:

Tivemos um tempo em que tínhamos pessoas preparadas e não tínhamos oportunidades. Isso era constrangedor. Agora, em cinco anos se gerou quase 500 mil empregos, o desemprego caiu [...] As oportunidades estão chegando e os pernambucanos estão entrando nessas oportunidades. Vamos ler os números como eles são! Nós tínhamos 15\% de desemprego. Reduzimos dois terços em cinco anos. Estamos fazendo um grande esforço na educação, que não se muda de um ano para o outro, mas sim de uma geração para outra.

Entretanto, a eclosão de uma onda de conflitos, protagonizada pelos peões ${ }^{8}$ dos canteiros de obra de Suape, realçou outros aspectos, produzindo deslocamentos nas dinâmicas das relações de trabalho, com repercussões econômicas e políticas. Especialmente a partir de 2011, revoltas, paralisações e greves, acompanhadas por confusos e tensos processos de negociação social e sindical, envolvendo os próprios peões, sindicatos, empre-

${ }^{8}$ Não se sabe, precisamente, onde e quando a expressão "peão" passou a ser usada, no Brasil, com o sentido de operário pouco ou sem qualificação. Um dos primeiros estudos a incorporar o termo com tal conotação foi o de Rainha (1980). sas, governos estadual e municipais, Ministério Público do Trabalho - MPT, Ministério do Trabalho e Emprego, Justiça do Trabalho, órgãos de mídia, entre outros, vêm marcando fortemente a cena da região.

Uma abordagem com foco em tais conflitos nos permitirá apreender os processos desencadeados (conflitos, mediações e negociações) e o que tem estado em disputa em tais processos (com as demandas dos trabalhadores e os discursos e práticas governamentais, empresariais e sindicais). Perguntamo-nos se, com essas mobilizações, para além de estarem conseguindo trazer ganhos imediatos para os trabalhadores, estes têm sido capazes de se fazer reconhecer ${ }^{9}$ como legítimos portadores de demandas sociais. Em que medida tais demandas vêm sendo não só objeto de denúncia pública, mas, também, de alguma elaboração, de modo a problematizar os termos com base nos quais emergiu uma nova perspectiva desenvolvimentista em Pernambuco e no país? ${ }^{10}$

Aqui, usamos a noção em um sentido mais próximo de Nancy Fraser (2008), em sua polêmica com Axel Honneth, a qual prefere tratar "reconhecimento" (dimensão cultural, simbólica) em associação com "redistribuição" (dimensão social). Quanto à situação que aqui analisamos, realçamos o quão imbricados, embora distintos, se encontram esses dois movimentos.

${ }^{10}$ Tanto quanto no contexto de implementação do projeto da Sudene, também agora, com o PAC e outras iniciativas de políticas de desenvolvimento do Governo Federal, a dinâmica econômica do Nordeste e de Pernambuco se encontram sob fortes vínculos com tais políticas. Mesmo se efetivando uma dissidência na coalizão de forças que dá sustentação ao Governo Dilma, protagonizada pelo Governador de Pernambuco, Eduardo Campos (questão essa que não será tratada aqui), consideramos que a orientação desenvolvimentista não só foi marcante no seu primeiro mandato (embalado pela proximidade política com Lula), como essa continua sendo uma referência no seu mandato atual (quando o mesmo tem mantido certa ambiguidade entre o apoio ao Governo Dilma e a assunção de uma posição de oposição). As obras do PAC, os projetos "estruturantes", os investimentos em Suape, os vinculam fortemente a um realce desenvolvimentista, não obstante certas nuances diferenciadoras entre ambos os projetos políticos e as possíveis divergências que venham a ser explicitadas entre seus expoentes (veja-se, por exemplo, polêmica entre Eduardo Campos e o Governo Dilma, quando da publicação da Medida Provisória 595, conhecida como MP dos Portos, em dezembro de 2012, tida para o primeiro como ameaça de perda de autonomia do Governo pernambucano sobre o Porto de Suape (JC, 26/ 03/2013). A análise das diferenciações práticas e discursivas aí implicadas certamente será de muita importância para o aprofundamento dessa reflexão. 


\section{A VOLTA DO DESENVOLVIMENTISMO: agen- da e debate}

O emblema maior do novo discurso desenvolvimentista do Governo Federal tem sido o PAC, lançado em 2007. O Governo Lula passou a incorporar o referencial do papel indutor do Estado com vistas ao crescimento econômico, realçando, ao mesmo tempo, o seu compromisso com a geração de emprego e renda e a estabilidade macroeconômica (Pêgo; Campos Neto, 2008). Objetivou-se, por meio de investimentos, principalmente em infraestrutura, aumentar a produtividade das empresas, estimular investimentos privados, gerar emprego e renda e reduzir as desigualdades regionais. Até 2010, segundo dados oficiais, foram investidos mais de $\mathrm{R} \$ 600$ bilhões, oriundos do Governo Federal, de empresas estatais e do setor privado, com destaque para os setores de energia, transporte, habitação, saneamento, recursos hídricos, além de programas de impacto social, como o "Minha Casa Minha Vida" (habitação) e o "Luz para Todos" (distribuição de energia elétrica). A participação do investimento total no PIB passou de 16,4\%, em 2006, para 18,4\%, em 2010 (Brasil, 2010). Em 2010, foi lançado o PAC 2, redefinindo, mas, sobretudo, confirmando, os eixos estruturantes da sua primeira edição (Brasil, 2012). Para Batista Jr. (2007), não obstante as críticas, ocorreu "uma mudança na orientação da política econômica”, onde essa "pode ser excessivamente cautelosa ou lenta, mas ela é significativa. O governo Lula está migrando, aos poucos, para o desenvolvimentismo, talvez um desenvolvimentismo "light”.

Os indicadores econômicos e sociais que, a partir de 2004, passaram a apresentar tendências sistematicamente positivas, podem ser creditados duplamente ao novo dinamismo econômico e às novas condições políticas, nas quais se estabeleceu um certo patamar de lutas salariais e sindicais. Em balanço recente, Krein et al (2012, p. 119) admitem que, na Era Lula, não só devem ser computados "os impactos positivos do aumento progressivo do dinamismo econômico sobre o mercado e as relações de trabalho no Brasil”, mas, tam- bém, é preciso que sejam destacadas que "as políticas públicas e as lutas e conquistas do movimento sindical foram decisivas para acrescentar melhorias ao mercado de trabalho brasileiro". Especialmente para os segmentos ligados à Central Única dos Trabalhadores - CUT, constituída sob relações históricas com o Partido dos Trabalhadores, prevaleceu, nesse momento, a adoção de uma estratégia ambivalente, que reforçou uma situação já presente nos anos 1990: a perda de protagonismo político do sindicalismo no cenário nacional, ao mesmo tempo em que o mesmo se manteve presente e atuante (Araújo; Véras de Oliveira, 2011). Ao lado da emergência de uma nova agenda e um novo discurso político orientado ao desenvolvimento, ressurgiu um debate acadêmico sobre o tema. O primeiro a utilizar a expressão "novo desenvolvimentismo" foi Bresser-Pereira (2003), para quem o fracasso da "ortodoxia neoliberal" em garantir estabilização macroeconômica e crescimento coloca a possibilidade de uma nova política econômica, na América Latina. Em contraste com o "populismo da esquerda burocrática e sindical" (herdeira do nacional desenvolvimentismo), propõe uma estratégia nacional de desenvolvimento sem protecionismo e com rigor fiscal e monetário, baseada em uma indústria competitiva, voltada à exportação. Requer Estado e mercado fortes, políticas públicas permanentes e flexibilização das relações de trabalho (Bresser-Pereira, 2006). Sicsú et al (2007) apostam no fortalecimento do "empresariado nacional" como "núcleo endógeno" do desenvolvimento, associado a um "Estado forte" e a um "pacto nacionalista", mas sem que se trate de um retorno à política de substituição de importações, ao protecionismo e ao Estado empresa. Atribuem maior ênfase, comparativamente a Bresser-Pereira, à compatibilização entre crescimento econômico e equidade social.

Ridenti (2009) questiona a pertinência do retorno do desenvolvimentismo, tão criticado no passado. Lembra que, sob tal referência, omitiram-se as contradições de classes, ao priorizarem-se as contradições entre nações. Por isso, é preciso não deixar de se perguntar: a quem serve o desenvolvimento? Isso, 
sob pena de serem reeditados os mesmos problemas do passado. Quanto a Fiori (2012a e 2012b), pergunta-se: por que o "desenvolvimentismo de esquerda”, ressurgido recentemente, estreitou-se tanto no seu "horizonte utópico", tornando-se uma "ideologia tecnocrática”, sem capacidade de mobilização social, não sendo, também, capaz de construir uma nova base teórica? Na sua crítica, o autor argumenta que a "Escola Campineira", embora surgida de uma crítica ao paradigma cepalino, teria sido sufocada, mais recentemente, com a crise socialista e a onda neoliberal, tendo perdido sua capacidade teórica e seu conteúdo político. Com a retomada do discurso desenvolvimentista, restaria a sensação de um "horizonte utópico" estreito, sem poder de mobilização. Em resposta a Luis Fiori, Carneiro (2012) propõe que o "novo desenvolvimentismo" é uma formulação da equipe da Fundação Getúlio Vargas - FGV/ SP, que privilegia as políticas macroeconômicas, subordinando a essas as políticas sociais, condicionando ganhos salariais à elevação da produtividade. Enquanto o "desenvolvimentismo de esquerda", centrado na UNICAMP ("Escola Campineira”) e na UFRJ, priorizaria a dimensão social do desenvolvimento.

Boschi (2011), discutindo o retorno do intervencionismo estatal na América Latina, insiste na dimensão social como fator de desenvolvimento e no papel estratégico do Estado como seu indutor e garantidor de inclusão social. Coloca, assim, em evidência a política, o projeto nacional, a necessidade de constituição de coalizões de apoio a um novo compromisso desenvolvimentista. Também para Pochmann (2012), a condição para um salto no desenvolvimento da América Latina é a constituição de uma "nova maioria política". Sobre o Brasil, haveria duas alternativas: uma orientada à exportação de commodities e a outra, a investimentos em valor agregado e em conhecimento. Apenas com investimentos nesta direção seria possível superar o subdesenvolvimento.

Para outros, a retomada de políticas de desenvolvimento justifica um novo ciclo de pesquisas sobre o tema. Eli Diniz (2011) destaca que, no mundo, vem ressurgindo um pensamento crítico ao liberalismo, assim como retorna a referência do desenvolvimento, com nova ênfase no papel do Estado, nas liberdades substantivas (Amartya Sen), na questão ambiental. Quanto ao Brasil, o crescimento e o emprego ganham importância. Observa, ainda, que, no debate atual, embora com diferenças, em geral se busca associar mercado e Estado, o econômico e o social, ganhos salariais e elevação da produtividade. Mas admite que ainda não se constituiu uma articulação de forças capaz de dar sustentação a um projeto desenvolvimentista. Draibe e Riesco (2011) propõem a adequação dos referenciais analíticos ao estudo das mudanças recentes nas políticas econômicas e sociais na América Latina, para melhor se avaliar sobre se está em gestação um novo desenvolvimentismo na região. Formulam a noção de Estado Latino-Americano Desenvolvimentista de Bem Estar-ELADBES, visando realçar a relação entre economia e política social. Sugerem que as atuais políticas desenvolvimentistas estariam repondo as articulações entre os dois âmbitos. Acrescentam, ainda, que, embora haja sinais de esgotamento do ciclo neoliberal, não parece se tratar de mero retorno ao desenvolvimentismo, nem simples reafirmação do neoliberalismo. O rumo a seguir será decidido no campo da política. Kerstenetzky (2011) também evidencia a relação entre desenvolvimento e equidade. Após constatar uma segmentação entre tais termos, propõe a sua conciliação, opondo-se ao argumento de que a possibilidade de construção de um Estado do bem estar social requer a existência prévia de desenvolvimento e de que o gasto social é, por si só, economicamente ineficiente. Defende como condição para tanto que as políticas sociais sejam economicamente orientadas e as políticas econômicas, socialmente orientadas.

Odebate, aqui brevemente mapeado, alimenta-se de uma agenda que vem se estabelecendo, no Brasil e na América Latina, sob um novo discurso desenvolvimentista. As diversas posições em geral reconhecem o retorno a um papel mais central do Estado na economia. Muitas vezes, sugerem alguma compatibilização entre desenvolvimento e equidade. Mas o modo de conceber essa relação é um aspecto de importante diferenciação entre as 
perspectivas adotadas. Destacar o lugar do social requer dar um realce especial ao momento da política, assim como tomar esta para além da discussão sobre o papel do Estado. Para Boschi (2011, p. 16), "as diversas políticas que se busca colocar em prática mobilizam atores e interesses que enfrentam um jogo de estratégias, uma dinâmica que, por natureza, é incerta”. Pôr em evidência a dimensão social do desenvolvimento requer tratar com centralidade a problemática do trabalho referida à questão da cidadania. Com Ivo (2012, p. 206):

Da minha perspectiva, considero que avaliar a relevância da agenda social do desenvolvimento hoje implica analisar um padrão decisivo do Estado na distribuição e no enfrentamento da dimensão estruturante e qualificada de inserção pelo mercado de trabalho e na proteção sustentada em direitos sociais, ou na regulação das relações não mercantis (base de que tratam as políticas sociais).

Para os estudiosos do trabalho, por seu lado, está posto o desafio de levar em conta as implicações da retomada das políticas de desenvolvimento quanto às condições, relações e ações coletivas laborais. É o que, por exemplo, se traduz em Ramalho e Fortes (2012, p. 09), quando se detêm sobre as experiências de desenvolvimento da Baixada e Sul fluminense, sob a perspectiva de "pensar as regiões como espaços sociais e históricos, com organizações políticas e identidades próprias, buscando nas particularidades regionais elementos que possam influenciar na construção de novos projetos de desenvolvimento e seus impactos sociais e econômicos". Entra, aqui, o elemento do território. A abordagem desses espaços regionais se faz com um foco nas questões do trabalho, sob a referência dos seus nexos com os modelos de desenvolvimento implementados no país ao longo do século XX e na passagem para o século XXI:

[...] se, na era nacional-desenvolvimentista, o trabalho assumiu um papel central na constituição de identidades coletivas e formas de participação política, como repensar a articulação entre esses elementos quando se retoma o debate sobre o desenvolvimento em um novo contexto? (Idem, p. 10).
É nesse registro que pretendemos discutir Suape (considerando seus vínculos com a nova agenda e discurso desenvolvimentistas em Pernambuco e no país) pela ótica dos conflitos do trabalho que lá vêm tendo lugar mais recentemente (com suas implicações recíprocas frente a tal agenda e discurso).

\section{TRABALHOE TRABALHADORES NA CONS- TRUÇÃO CIVIL EM SUAPE}

\section{Evidências de um desenvolvimento contraditório}

É evidente o excelente momento da economia pernambucana. Enquanto o PIB do Brasil cresceu, de 2005 a 2012, a taxas anuais de 2,9\%, 3,8\%, $5,4 \%, 5,1 \%,-0,2 \%, 7,5 \%, 2,7 \%$ e $0,9 \%$, respectivamente; o de Pernambuco, na mesma sequência de anos, teve um melhor desempenho: 4,2\%, 5,1\%, $5,4 \%, 5,3 \%, 5,2 \%, 9,3 \%, 4,5 \%$ e 2,3\% (IBGE, 2005 a 2012). Tal performance se reflete nos indicadores econômicos de Ipojuca e Cabo de Santo Agostinho, graças a Suape. Em 2003, Ipojuca já detinha o quarto maior PIB de Pernambuco (5,9\%), com Cabo em terceiro (6,2\%), Jaboatão em segundo (8,5\%) e Recife em primeiro (33,3\%). Em 2005, o PIB per capita de Ipojuca se tornou o maior do Estado, representando mais de 4,6 vezes o da cidade de Recife. Em 2007, o PIB de Ipojuca passou a terceiro, invertendo sua posição com Cabo. Em 2010, chega ao segundo lugar (com 9,6\% do PIB estadual), alcançando um PIB per capita de 5,8 vezes o da capital (IBGE, 2003 a 2010). O crescimento populacional em Cabo e Ipojuca também teve evolução expressiva, sendo de $21,0 \%$ e $36,0 \%$, respectivamente, em 2000 e 2010; enquanto o Nordeste e Pernambuco cresceram no mesmo período, correspondentemente, $11,1 \%$ e 10,9\% (IBGE, 2000 e 2010).

Entretanto, a problemática social persiste. Enquanto Ipojuca registrou um PIB per capita, em 2010, a preços correntes, de R $\$ 112.924,25$, o valor do rendimento nominal médio mensal per capita dos domicílios particulares permanentes, para o 
mesmo ano, ficou em R \$ 416,18 - abaixo do Salário Mínimo, que, na época, era de R\$ 510,00 (IBGE, 2010). Em Ipojuca, a taxa de analfabetismo, embora tenha caído, entre 2000 e 2010, de 28,7\% para $19,2 \%$, manteve-se acima das verificadas para Pernambuco, 18,0\%, Nordeste, 19,1\%, e Brasil, 9,6\% (IBGE, 2000 e 2010). Uma já comprometida infraestrutura urbana e de serviços passou a sofrer uma forte pressão com o extraordinário fluxo migratório para a região (Monteiro, 2011).

Nessa fase de implantação dos maiores empreendimentos de Suape, ganham destaque os impactos da construção civil nas dinâmicas econômica e social da região.

\section{Emprego na RMR e na construção civil em Cabo e Ipojuca}

Entre fevereiro de 2003 e de 2013, a taxa de desocupação da RMR caiu de $12,1 \%$ para $6,5 \%$. No mesmo período, os empregados com carteira de trabalho assinada no setor privado passaram de $35,0 \%$ para $47,1 \%$ do total e os empregados sem carteira de trabalho assinada no setor privado, de 15,1\% para 10,0\%. Um claro sinal de melhora no perfil da ocupação da região, mesmo considerando-se que esta passou a receber significativos fluxos migratórios, invertendo-se a direção histórica dos mesmos. Quanto ao rendimento médio real entre janeiro de 2003 e março de 2013 habitual da população ocupada, para o mesmo período, também cresceu, passando de R\$ 1.057,25 para $\mathrm{R} \$ 1.376,00$, embora sempre se mantendo em patamares mais baixos, quando comparados ao conjunto das RM pesquisadas (que passou de $\mathrm{R} \$$ $1.555,33$ para $\mathrm{R} \$ 1.849,50$, no mesmo intervalo) (IBGE/PME, 2003 a 2013).

Nesse contexto, o setor da construção civil na RMR, observado pela distribuição da população ocupada, ganhou crescente participação, com estoques de ocupação cada vez maiores. Passou de $5,7 \%$, em fevereiro de 2005, para 7,6\%, em fevereiro de 2007 e 7,8\%, em fevereiro de 2013. Entre fevereiro de 2005 e de 2013, os empregados com carteira de trabalho assinada no setor privado tiveram aumento expressivo, passando de $24,7 \%$ para $42,5 \%$ do total de ocupados no setor, respectivamente. Isso, enquanto os empregados sem carteira de trabalho assinada no setor privado passaram de 24,9\% para 13,5\% e os “por conta própria”, de 43,9\% para 37,2\% (IBGE/PME, 2005, 2007 e 2013).

Para o município de Ipojuca, a Tabela 1 mostra a evolução da dinâmica do emprego formal na Construção Civil, de janeiro de 2006 a março de 2013. Destaque-se a elevação do nível de contratação em 2009 (coincidindo com o início das obras de terraplanagem da Refinaria e da Petroquímica), assim como em 2010 (quando começaram as obras de construção das duas plantas industriais ${ }^{11}$ ). Mas o grande salto no nível de

Tabela 1 - Estoques de emprego, admissões e demissões na indústria da construção civil no município de Ipojuca,

\begin{tabular}{|c|c|c|c|c|c|c|}
\hline Período (Jan a Dez) & Estoque Inicial & Admissões (A & & Demissões (D) & Saldo $(D-A)$ & Estoque Final \\
\hline 2006 & 6.948 & 2.117 & & 1.899 & 218 & 7.166 \\
\hline 2007 & 7.166 & 2.219 & & 2.114 & 105 & 7.271 \\
\hline 2008 & 7.271 & 5.174 & & 3.538 & 1.636 & 8.907 \\
\hline 2009 & 8.907 & 7.791 & & 6.760 & 1.031 & 9.938 \\
\hline 2010 & 9.938 & 25.270 & & 10.719 & 14.551 & 24.489 \\
\hline 2011 & 24.489 & 36.992 & & 29.451 & 7.541 & 32.030 \\
\hline 2012 & 32.030 & 28.613 & & 25.322 & 3.291 & 35.321 \\
\hline $2013^{*}$ & 35.321 & 4.920 & & 3.659 & 1.261 & 36.582 \\
\hline \multicolumn{7}{|l|}{$\begin{array}{l}\text { Fonte: MTE/CAGED } \\
{ }^{*} \text { De jan. a mar. de } 2013\end{array}$} \\
\hline \multicolumn{7}{|c|}{$\begin{array}{l}{ }^{11} \text { Para a construção da planta da Refinaria Abreu e Lima, a } \\
\text { Petrobras firmou contratos com cinco consórcios, no } \\
\text { valor global de R\$ 8,9 bilhões: Camargo Corrêa - CNEC } \\
\text { (R\$ 3,4 bilhões); Conest-UHDT, formado pelas empre- }\end{array}$} \\
\hline
\end{tabular}


contratação ocorreu a partir de 2011, quando as referidas obras ganharam ritmo. Sobressai, ainda, a rotatividade no emprego, atingindo em 2012 as impressionantes marcas de 36.992 admissões e 29.451 demissões. $^{12}$

Ainda sobre o perfil do emprego formal na construção civil em Ipojuca, entre janeiro de 2008 e de 2013, destaca-se, pelo elevado volume de contrações, baixo nível salarial e extraordinária rotatividade no emprego, o segmento de serventes de obras (17.612 admissões, 10.428 desligamentos, 7.184 de saldo, com salário médio de admissão de R \$ 637,05). Mas, de outra parte, evidenciase, também, a elevada e diversificada demanda por ocupações com maiores exigências de qualificação profissional (exemplos: instalador de tubulações, montador de estruturas metálicas, soldador, entre outros) (MTE/CAGED, 2003 a 2013).

\section{Qualificação como necessidade, oportunida- de e justificação}

Em reportagem da Revista Exame (07/04/ 2010), evidenciando o descompasso entre o crescimento econômico e a disponibilidade de mão de obra qualificada, Marcelo Odebrecht, presidente do grupo que leva seu nome, comentou: "a falta de gente qualificada é uma de nossas piores fraquezas, pois impede que o país cresça por vários anos seguidos". Órgãos de mídia, em tom sensacionalista, têm falado de "apagão de mão de obra". ${ }^{13}$ Estudo de Moutinho et al (2011), diante da crescente carência de trabalhadores qualificados para

\footnotetext{
${ }^{12}$ Isso, provavelmente, se deve a causas diversas. Entre as quais, podemos considerar: essa é uma característica do setor (contratações por empreitadas e alto grau de subcontratação); trata-se de uma estratégia empresarial recorrente na gestão do emprego no Brasil, com o fim de rebaixar salário; pode ser um recurso usado pelos trabalhadores, em condições de demanda de mão de obra aquecida, com o propósito de barganhar melhores salários e condições de trabalho. No caso em particular, avaliamos que tal questão merece análise mais detida, ao mesmo tempo em que admitimos que o primeiro elemento tem tido um peso mais decisivo.

${ }^{13}$ Ver, por exemplo, matéria do Jornal Nacional, no site Globo.com (http://g1.globo.com/jornal-nacional/noticia/ 2012/08/dificuldade-de-encontrar-mao-de-obra-qualificada-afeta-economia-brasileira.html).
}

os diversos novos segmentos produtivos em Suape, evidenciou o desafio de converter trabalhadores com baixa escolaridade em operários qualificados. Também Monteiro (2011) comentou que as elevadas exigências de qualificação profissional contrastavam com o perfil da mão de obra disponível na região, destacando esse como um grande problema para os novos empreendimentos.

Essa questão se tornou, assim, um decisivo desafio da política de desenvolvimento no Brasil e em Pernambuco, ao se situar entre, de um lado, as demandas empresariais (para que seja disponibilizada mão de obra que atenda às suas necessidades de qualificação e em quantidade suficiente para que os salários possam ser mantidos em padrões competitivos) e, de outro, as demandas dos trabalhadores (para que agora sejam criadas - especialmente para os pernambucanos oportunidades de uma melhor inserção no mercado de trabalho). A legitimação das políticas públicas de qualificação profissional dependem, nesse contexto, de sua capacidade de se colocarem como centrais, para ambas as demandas, ao mesmo tempo em que as venham atender, em alguma medida. Notamos, quanto a esse aspecto, um quê de ambiguidade discursiva. No caso aqui em tela, nas palavras de Eduardo Campos, diante do sucesso econômico de Suape,

[...] o desafio agora é capacitar a população para a nova realidade do nosso mercado de trabalho. Parcerias, convênios e contratos estão promovendo uma inédita mobilização em prol da formação e especialização da mão de obra pernambucana (Suape/Governo Pernambuco, 2010).

O elemento de ambiguidade, para fins de justificação, requer que os agentes estratégicos da agenda desenvolvimentista, governantes e empresários, afinem o discurso. Neste, as demandas acima referidas tendem a ser enunciadas como (quase) uma mesma questão. Não fica suficientemente explícito no discurso governamental, como indica o fragmento acima, que a ação do Estado nessa área não pode, necessariamente, deixar de lidar com, pelo menos, essas duas visões do problema, diferentes nos seus sentidos, podendo implicar 
diversas formas de conflitos de perspectivas, assim como de acertos, composições. ${ }^{14}$ Entretanto, como o encaminhamento do problema não tem implicado uma franca explicitação dessas diferenças de perspectiva, nem o reconhecimento público dos conflitos que implicam, a questão não tem sido posta claramente em termos de contratação social, mas de atendimento, por parte do Estado (monologicamente), da demanda da sociedade.

O encaminhamento prático da questão, no entanto, ao mesmo tempo em que confirma essa perspectiva, problematiza-a parcialmente. A primeira grande ação de qualificação profissional no território de Suape foi, segundo Arioneide Belém, da Superintendência Regional do Trabalho e Emprego de Pernambuco - SRTE/PE (entrevistada pelo autor em março de 2013), a realização do Plano Setorial de Qualificação - PLANSEQ da Construção Civil, contando com recursos do Fundo de Amparo ao Trabalhador - FAT e das empresas beneficiadas. Uma edição esteve voltada à qualificação para máquinas pesadas (de 2007 a 2010), e outras duas para segmentos mais leves (2007-2008 e 2010-2011). Em ambas foram constituídas Comissões de Concertação, reunindo empresas, sindicatos, SRTE, Senai, e outras instituições. Destacou a entrevistada que, diante da baixa escolarização dos trabalhadores da região, foi preciso diminuir as exigências inicialmente estabelecidas, de modo a ampliar o número de cursistas. Para a Secretária Executiva de Trabalho e Qualificação de Pernambuco, Angela Mochel (entrevistada pelo autor e equipe da Fundaj, em dezembro de 2012), o Estaleiro Atlântico SulEAS foi um marco no perfil da demanda por mão de obra no estado. Intenso processo de discussão se estabeleceu em torno do cadastramento, seleção e treinamento, envolvendo o Estaleiro, as Agências do Trabalho, prefeituras da região de Suape, Senai. Segundo informações do Senai-Pe (O Estado de São Paulo, 30/08/2010), o número de alunos formados

${ }^{14}$ Vista como construção social, em perspectiva relacional, enquanto produto das disputas sociais e dos aspectos valorativos que se encontram na base dos julgamentos e classificações sociais sobre o trabalho, a noção de qualificação se refere às possibilidades trazidas com as diversas condições sociais, econômicas, políticas e culturais (ver quanto a isso a clássica abordagem de Naville, [1956] 2012). pela instituição passou, de 19,4 mil para 48,6 mil, entre 2003 a 2010. Com as demandas do setor de petróleo e gás, o Senai-Pe executou, em 2009, o Programa de Mobilização da Indústria Nacional de Petróleo e Gás Natural - PROMINP (do Ministério das Minas e Energia em parceria com a Petrobras). Segundo Soares Júnior e Martins (2010), o orçamento do Proninp/Senai-Pe, para 2009, foi de mais de R $\$ 10$ milhões, envolvendo 14 cursos, 389 turmas e mais de 6,2 mil alunos. Até 2010 , o governo de Pernambuco havia criado 13 novas escolas técnicas, frente a um total de 16, disponibilizando 13 mil vagas. Outras ações nesse campo se estabeleceram, envolvendo a FIEPE, governos municipais, Universidades, SEBRAE, BNDES, grandes empresas (Monteiro, 2011; Soares Júnior e Martins, 2010).

Após tantas iniciativas no campo da qualificação profissional, embora tenham sido anunciadas como oportunidades de uma nova inserção das populações locais no mercado de trabalho, fica o alerta do ex-prefeito de Ipojuca, Pedro Serafim, em entrevista para o JC (12/08/2011): “ainda ficamos com os menores salários". Mesmo havendo significativa incorporação de trabalhadores locais aos empreendimentos de Suape (com destaque para a construção civil) e mesmo considerando que tal incorporação tem implicado conversão ocupacional (com os segmentos majoritários sendo oriundos da lavoura da cana de açúcar), com elevação significativa dos empregos com carteira assinada, isso não tem significado a instauração de um padrão salarial e de condições de trabalho muito diferentes dos padrões históricos da região. Os conflitos que serão analisados denunciam tal situação.

\section{Reconstituições identitárias}

A região de Suape tem a marca histórica do trabalho na cana-de-açúcar, na pesca artesanal e, mais recentemente, no turismo. Com o Complexo Suape, estabeleceu-se entre este e as comunidades locais uma dinâmica de conflitos, intensificados, nas décadas de 1990 e 2000, com ações de expropriação (Pérez e Gonçalves, 2012). Para Santos 
(2012), existem, ainda, 28 mil pessoas residindo dentro do perímetro do Complexo. Tais conflitos, associados à decadência da base produtiva anterior, têm afetado, significativamente, as comunidades locais, em sua reprodução e identidades. ${ }^{15}$

Quanto aos moradores da região, absorvidos nos novos empreendimentos, estão vivenciando um processo de reconversão ocupacional e identitária. ${ }^{16}$ Em contraste com suas trajetórias ocupacionais anteriores, veem-se, agora, imersos na rotina de empresas estruturadas, formais, algumas de grande porte. Para muitos desses, o sentimento é de melhora de vida e até de euforia, a exemplo de uma operária citada por Rodrigues (2012, p. 39):

[...] esse é o meu primeiro emprego. Antes eu era uma dona de casa, agora sou metalúrgicasoldadora do EAS, que vai construir grandes navios. O presidente Lula sabe o que isso significa. Me sinto honrada em fazer parte disso, em saber que cada um desses navios terá um pedacinho de mim.

O discurso desenvolvimentista encontra nesse tipo de manifestação (da parte dos trabalhadores oriundos da região e recém-incorporados aos novos empreendimentos de Suape) uma percepção que o complementa e o legitima.

Os trabalhadores dos empreendimentos de Suape são de dois tipos principais: os moradores da região e os trabalhadores vindos de fora, os "trecheiros". ${ }^{17}$ Quanto aos primeiros, "normalmen-

${ }^{15}$ Em depoimento a Cavalcanti e Rocha (2013, p. 10), um dos moradores da comunidade Tatuoca, assim se colocou: "tudo que sou tá ligado a Tatuoca! Pra nós, nativos, SUAPE não trouxe benefício. Tiraram muito da nossa sobrevivência. Vivo da pesca e de outro giro das frutas que comercializo. Aqui muitas empresas desmataram, não deram satisfação à gente. E a gente manteve a terra".

${ }^{16}$ Em depoimento a Cavalcanti e Rocha (2013, p. 13), um diretor do Sindicato dos Trabalhadores Rurais de Ipojuca admitiu: "o trabalhador rural, 60\% deles foi trabalhar em Suape. Quem foi trabalhar em Suape, não volta mais para o campo, não quer ser mais cortador de cana. Esse já fez treinamento, já adquiriu outro conhecimento, não volta mais para ser um cortador de cana”.

${ }^{17}$ Para Guedes (2011, p. 182), a origem dos termos "trecho" e "trecheiro" pode ter tido relação com a prática de divisão, entre empreiteiras, do serviço referente a uma grande obra de construção de estrada, em "trechos". Indica que, em trabalhos mais recentes, o termo "trecheiro" passou a ser usado com um sentido alargado, como "intinerante". Propõe que a noção se estabeleça em contraste com a de "migrante", cujo "trajeto se justifica pelo ponto que está em seu fim”, enquanto para o primeiro "a circulação é um objetivo em si mesmo". Nesse enquadramento inclui os "peões de obra". te, são contratados para ocupar os postos de trabalho mais baixos na hierarquia da obra" (Rodrigues, 2012, p. 43). Conforme apurou Rodrigues (2012), as empresas, em Suape, se utilizaram da estratégia de treinamento de trabalhadores agrícolas, como forma de poder dispor de mão de obra barata e dócil. Entre os trabalhadores oriundos da região e os "trecheiros", em Suape, as diferenças de perfil têm redundado em tensões. Sendo que esses últimos, segundo apurou Rodrigues (2012), têm trazido, de andanças pelo Brasil, não só uma experiência profissional, mas, também, sindical e política.

\section{Sindicatos em Suape}

Para o sindicalismo, Suape tornou-se um grande desafio. Requer saber lidar com: grandes empresas; concentrações de trabalhadores; heterogeneidade no seu perfil; discrepâncias salariais e de condições de trabalho; caráter explosivo dos conflitos; intensas disputas sindicais. Em geral, os sindicalistas não têm conseguido se legitimar como representantes das demandas dos trabalhadores. Para os principais sindicatos filiados à CUT, com base na região, o Sindmetal-Pe (Metalúrgicos), o Sindipetro- $\mathrm{Pe} / \mathrm{Pb}$ (Petroleiros), o Sindiquímica-Pe (Químicos), o Sticc/Pe (Construção Civil), prevalece, ainda, uma postura de certa perplexidade, segundo evidenciou um dirigente do Sindmetal-Pe (entrevistado pelo autor em março de 2013). Isso tem se traduzido, em geral, em níveis baixíssimos de sindicalização. Para um dirigente do Sindipetro- $\mathrm{Pe} / \mathrm{Pb}$ (entrevistado pelo autor em março de 2013), este tem uma situação diferenciada, visto que as empresas da Petrobras, em Suape, são suas principais bases de atuação. Quanto à Força Sindical, antecipando-se ao boom da construção civil, trazido com o PAC, criou, em 2000, o Sintepav-Pe (para a construção civil "pesada”), aproveitando-se da desatenção do Sticc/Pe (conhecido como "Marreta"), criado em 1919 e filiado à CUT desde os anos 1980. O Sintepav-Pe passou a representar, legalmente, os trabalhadores da Construção Civil "pesada” em Pernambuco, 
incluindo Suape. O seu fundador e presidente é o mesmo que, atualmente, preside a Força Sindical no estado, Aldo Amaral. A Conlutas também tem tido atuação em Suape. Embora não detenha representação legal nas empresas do Complexo, essa Central tem deslocado militantes para atuarem nos conflitos da região, tendo conseguido conquistar o direito de participar em assembleias e mesas de negociação (Rodrigo, 2012).

A atuação sindical no setor da construção civil no Brasil tem tido, nos processos de terceirização, um desafio especial. Segundo Cockell e Perticarrari (2010, p. 635), embora tais práticas tenham como motivação a busca de serviços especializados, visam, sobretudo, reduzir custos trabalhistas, quando são subcontratadas empresas arregimentadoras de mão de obra, denominadas "gatos". As subcontratações podem levar a processos sucessivos, quando subcontratadas subcontratam outras empresas. As condições de trabalho se diferenciam ao longo dessa cadeia. O mesmo ocorre em Suape, onde são praticadas diferenças contrastantes em aspectos como salários, acomodações, ${ }^{18}$ alimentação, transporte, entre outros (Monteiro, 2011; Rodrigues, 2012).

Os contrastes salariais e de condições de trabalho entre "trecheiros" e trabalhadores da região e entre contratados diretos e subcontratados, associados a atrasos em pagamentos, relações com chefias, entre outras situações, têm sido fatores de importantes conflitos nos canteiros de obra em Suape.

\section{AS LUTAS DOS PEÕES DE SUAPE: O QUE querem dizer?}

No processo de construção dos empreendimentos de Suape, os conflitos foram se acumulando no ritmo das obras. Em janeiro de 2008, ocorreu uma paralisação de dois dias dos 2 mil traba-

${ }^{18}$ Os trabalhadores chegados de fora são abrigados em alojamentos das empresas, hotéis, pousadas, "puxadinhos" em residências. Os consórcios constituídos para empreenderem as obras de construção civil em Suape construíam alojamentos. O Conest instalou um com capacidade para 3.688 trabalhadores, a Camargo Corrêa, para 3.500, a Odebrecht, para 1.296, a KMA 992 totalizando 9.476 lugares. (Monteiro, 2011). lhadores atuantes nos serviços de terraplanagem da Refinaria. Queixas: não-pagamento de horas extras, atraso de salários, maus tratos pelas chefes (Jornal Tribuna Popular, 30/01/2008). No mesmo ano, ocorreu a primeira greve dos trabalhadores do EAS, com duração de três dias (Rodrigues, 2012). No início de 2009, os dois mil trabalhadores ainda atuantes nas obras do EAS realizaram paralisação de um dia, em protesto pelo não pagamento da Participação nos Lucros (DP, 04/03/2009). Em 2010, os 3 mil trabalhadores do Consórcio Conest, formado pelas construtoras Odebrecht e OAS, realizaram uma paralisação de um dia, contra o plano de compensação das folgas de fim de ano. Em novembro, os mesmos trabalhadores protestaram pelos salários inferiores pagos aos trabalhadores da região, mesmo para funções iguais (A Verdade, 04/11/2010, www.averdade.org.br).

\section{Revoltas e greves em 2011}

Em 25 de janeiro de 2011, os sete mil trabalhadores da Odebrecht, envolvidos na construção da Petroquímica, paralisaram o trabalho, por aumento de $30 \%$ de adicional de periculosidade e melhorias nas condições de trabalho (DP, 09/02/ 2011). No dia 2 de fevereiro, o Tribunal Regional do Trabalho-TRT decretou a greve ilegal. Na noite do mesmo dia, em protesto, um alojamento foi incendiado. Ocorreram demissões e um trabalhador foi preso. Sucederam-se novas depredações (JC, 03/02/2011). No dia seguinte, foi formada uma comissão de seis trabalhadores, para representar suas demandas (JC, 20/02/2011). No dia 9, em assembleia no pátio de acesso à Refinaria, com mais de cinco mil trabalhadores, e sob um clima de tensões, o Sindicato defendeu que as reivindicações deveriam ser remetidas para a data-base da categoria, em agosto. Um conflito se estabeleceu, sendo protagonizado, de um lado, pelos "baianos", revoltados com a posição dos sindicalistas e, de outro lado, por estes, que passaram a desqualificar aqueles como "preguiçosos" e descomprometidos com o desenvolvimento de Pernambuco. Procurado 
pelo JC (20/02/2011), o presidente do Sintepav-Pe não admitiu as "expressões mais fortes", mas reconheceu que acusou os "baianos" de "falta de interesse no crescimento econômico do Estado". Chamam a atenção três aspectos da participação do Sindicato no episódio: as dificuldades de afirmação da sua liderança perante os trabalhadores inquietos; a adoção de uma estratégia divisionista, alimentando uma tensão latente (entre "pernambucanos" e "baianos"); o recurso ao argumento do "compromisso com o desenvolvimento de Pernambuco", para justificar a desmobilização dos trabalhadores. Entretanto, os acontecimentos evoluíram na direção oposta: a revolta uniu pernambucanos e "forasteiros". A tensão cresceu, houve empurra-empurra, e os dirigentes do Sindicato se viram acantonados... Um tiro foi disparado, atingindo um trabalhador baiano. Um segurança do Sintepav-Pe foi preso, acusado de "atirar na multidão” (JC, 20/02/2011). Grupos de trabalhadores se dirigiram à rodovia PE-60, bloqueando, assim, a principal via de acesso a Suape. Com a chegada da polícia, se estabeleceu um momento de negociação. A principal reivindicação dos manifestantes foi a “presença da imprensa” (Rodrigues, 2012, p. 54). Curioso o fato de ter imperado entre os revoltosos, na ocasião, a necessidade de buscar tornar visíveis, para a sociedade, as suas demandas. Sintomático que a superexposição dos assuntos de Suape, do novo discurso e agenda desenvolvimentistas tenham convivido, até então, com o silêncio dos seus protagonistas (governantes e empresários, mas, também, sindicalistas), sobre as condições de trabalho de contingentes tão significativos de trabalhadores.

No dia 14 de fevereiro, previsto para a volta ao trabalho, o clima era ainda tenso, com policiais presentes. No pátio de acesso à Refinaria, formouse uma assembleia, com o apoio de militantes da Conlutas. A paralisação foi mantida, sendo constituída uma comissão de oito trabalhadores (Rodrigues, 2012). Na versão do presidente do Sintepav-Pe, as manifestações tinham motivação política (DP, 15/02/2011). Já para Adalberto Silva, um dos membros da comissão, o Sindicato defendia "os interesses da construtora e não as necessi- dades dos trabalhadores” (DP, 15/02/2011). A comissão seguiu para o MPT, que passou a mediar as negociações. A primeira audiência ocorreu no dia 16 de fevereiro. Estiveram representados: o Governo Estadual (Secretarias do Trabalho, Qualificação e Empreendimentos, da Articulação Social e Regional, da Defesa Social e do Corpo de Bombeiros Militar de Pernambuco); os empresários (Conest, Petrobras, Sindicato Nacional da Indústria da Construção Pesada-SINICON, Confederação Nacional da Indústria e Construção); os trabalhadores (Sintepav-Pe; Federação Nacional dos Trabalhadores da Indústria da Construção Pesada FENATRACOP, Comissão dos Trabalhadores); a SRTE-PE/MTE; a Prefeitura Municipal de Ipojuca, entre outros (Rodrigues, 2012). Chamou a atenção o fato de não haver, ali, uma pauta de reivindicações. A dificuldade (ou indisponibilidade) do Sindicato em atuar como uma agência social ${ }^{19}$ processadora das demandas dos trabalhadores, e o caráter incipiente da comissão, mesmo diante de queixas e exigências que pululavam entre os trabalhadores, é o que, provavelmente, explica tal situação. Nas palavras do Procurador Geral, Fábio Freitas: "naquele primeiro momento de reivindicação, o Sindicato, praticamente, ele não falou"; acrescentando: sua presença se justificou pelo "aspecto legal" (depoimento dado a Rodrigues, 2012, p. 58). Os primeiros resultados das negociações foram: a suspensão do pedido de dissídio pelo Sinicon; o reconhecimento da comissão para compor a mesa de negociação e a garantia de estabilidade de 60 dias para seus membros; garantia de que não seriam descontados os dias parados enquanto durassem as negociações; suspensão imediata do movimento grevista enquanto durassem as negociações. Para Adalberto da Silva, a audiência legitimou o processo de negociação. Agora, era preciso validar, junto aos trabalhadores, os acordos firmados: "estamos no processo de convencimento entre nossos companheiros para mostrar

${ }^{19}$ Faço uso dessa expressão por alusão ao sentido dado por Sader (1988, p. 143), ao se referir à emergência entre os anos 1970 e 1980, no Brasil, de "novas formas de agenciamento social", capazes de elaborarem novas "matrizes discursivas". 
que essa é a melhor maneira encontrada de atingir nossos objetivos" (DP, 17/02/2011). Para a comissão, em particular, estava sendo travada uma dupla luta por reconhecimento: de um lado, das demandas dos trabalhadores frente à mesa de negociações; de outro, de si mesma junto aos trabalhadores.

No dia 23 de fevereiro, na segunda audiência, ainda sem que fosse apresentada uma pauta de reivindicações, foi formulada uma proposta, a qual foi assinada pela comissão, Fenatracop e Confederação Nacional da Indústria e Construção, mas não pelo Sintepav-Pe. Entre os 13 pontos apresentados, constaram: pagamento de 3 hs in itinere aos trabalhadores; estabilidade para a comissão por um ano; reclassificação dos trabalhadores em desvio de função, com correção salarial; reajuste do vale alimentação de $\mathrm{R} \$ 40,00$ para $\mathrm{R}$ \$ 300,00, por mês; pagamento de adicional de horas extras aos sábados, de 50\% para 100\%; não desconto dos dias parados (Rodrigues, 2012). As audiências e o processo de negociação seguiram. Entre uma e outra, os trabalhadores se reuniam em assembleia. Entretanto, conforme observou Fábio Freitas, o Sindicato estava tão "desprestigiado" que não participou daquelas assembleias (depoimento dado a Rodrigues, 2012, p. 63). Embora se tenha chegado, na audiência no dia 15 de março, a um acordo sobre alguns itens (ajuste no vale alimentação para $\mathrm{R} \$$ 130,00, estabilidade de um ano para a Comissão, abono dos dias parados, pagamento de 80\% para horas extras), com outros sendo remetidos a uma avaliação posterior (pagamento das horas in itinere) e ou à data base (auxílio residência), os trabalhadores recusaram o valor do auxílio refeição, que não deveria ser menor do que $\mathrm{R} \$ 160,00$, e o percentual de aumento pelas horas extras, que não deveria ser menor do que 100\% (JC, 18/03/2011). Era mais um forte indicativo da falta de representatividade do Sindicato, e mesmo da comissão.

A insatisfação entre os trabalhadores permanecia. ${ }^{20}$ Um operário do Conest, em depoimen-

${ }^{20}$ Nesse período, a SRTE/PE, com apoio do MPT, realizou uma Auditoria Fiscal do Trabalho no Complexo Suape (incluindo o EAS e os canteiros da Refinaria e da Petroquímica), na qual se registraram "casos de excesso de jornada, ocorrências de acidentes, falta de registro em carteira de trabalho, atrasos nos pagamentos e to ao jornal A Nova Democracia (Ano IX, $n^{0} 75$, mar/2011, http://www.anovademocracia.com.br), comenta: “o governo na televisão fala que Suape é uma maravilha” (um elemento de fissura na dimensão justificadora do discurso desenvolvimentista?). A paralisação, agora, havia sido estendida para os demais canteiros de obras de Suape, envolvendo cerca de 35 mil trabalhadores. Após outra rodada de negociações, os trabalhadores, em assembleia, no dia 25, optaram pela manutenção da greve (JC, 25/03/2011). Na nona audiência, ocorrida no dia 28 de março, o Procurador admitiu que havia chegado ao limite sua tentativa de mediar as negociações (ATA, 28/03/2011, apud Rodrigues, 2012, p. 65). No dia 29 de março, o TRT declarou a greve ilegal e, ao mesmo tempo, foram atendidos os $100 \%$ no pagamento das horas extras e os R\$160,00 de vale alimentação (DP, 29/03/2011).

Segundo Adalberto Silva, com vistas à convenção coletiva da categoria, em agosto, era preciso buscar a unificação dos salários e benefícios entre as empresas em âmbito nacional. No dia 15 de abril, na décima audiência, as negociações foram concluídas sem que as partes chegassem a um acordo sobre o desconto dos dias parados (Rodrigo, 2012). Nos canteiros de obras, os conflitos continuaram. Os trabalhadores seguiam insatisfeitos:

Quando reclamamos do péssimo tratamento, das horas extras que quase nunca pagam e das péssimas condições de trabalho, eles gritam com a gente coisas como: "vocês eram cortadores de cana, passavam fome e hoje tem profissão e salário, tão reclamando de que? Até fardinha vocês têm.” Veja que absurdo! (A Nova Democracia, Ano IX, $n^{\circ} 76$, abril de 2011).

Naquelemomento, em levantamento feito pelo DIEESE(UOL Notícias, 04/04/2011), foi estimado em 170 mil o número de grevistas da construção civil em todo o país, sobretudo envolvendo as obras do PAC. Em geral, as reivindicações se relacionavam a: condições de trabalho; salários; alojamentos, pagamento de horas extras; equalização de direitos entre superlotação de alojamentos" (SINAIT, 25/04/2011 http://www.sinait.org.br). Para Vera Jatobá, que coordenou a missão, chamou a atenção o alto grau de subcontratação praticado na região (entrevistada pelo autor em março de 2013). 
contratantes e subcontratadas, entre outros. Diante da repercussão das mobilizações, as Centrais Sindicais obtiveram do Governo Federal o compromisso com uma agenda nacional de negociações, sobre condições de trabalho nas obras do PAC, envolvendo empresários, Governo e sindicalistas.

Em Suape, nas mobilizações da data-base em julho, havia um clima de insatisfação com a resistência das empresas em abonar os dias parados na greve de fevereiro e março. No dia $1^{\circ}$ de agosto, foi aprovado o indicativo de greve. Diante do fato, em nota oficial, o Sinicon entra com pedido de ilegalidade da greve e justifica, acusando o Sintepav-Pe de "atropelar as negociações", quando "vários itens da pauta de reivindicação já tinham sido concedidos pela categoria patronal" (G1.globo.com, 02/08/ 2011 - http://g1.globo.com/economia/noticia/2011/ 08/trabalhadores-do-complexo-de-suape-estao-emgreve.html). Segundo o Sintepav-Pe, a proposta patronal não era suficiente. A luta era por 15\% de aumento, cesta básica de $\mathrm{R} \$ 300,00$, abono dos dias parados na última greve (Força Sindical, 02/08/2011 - http://www.fsindical.org.br). Em 5 de agosto, os trabalhadores suspendem a greve. Foram negociados: aumento salarial de $11 \%$, cesta básica de R $\$$ 200; abono de $50 \%$ dos dias parados na greve de março; abono total da greve de agosto; concessão de passagens aéreas para os que moram a mais de 1 mil km; redução do tempo de folga de campo (cinco dias), com 90 dias de intervalo. Desta vez, o secretário de Articulação Social e Regional de Pernambuco participou das negociações (G1.globo.com, 05/08/ 2011). O apelo discursivo do "desenvolvimento de Pernambuco” ganha, assim, mais evidência. Não à toa, a advogada do Sinicon introduziu a seguinte frase: "nós temos um compromisso com o desenvolvimento de Pernambuco” (DP, 06/08/2011).

\section{Em 2012, nova onda de mobilizações}

Em fevereiro, os cerca de dez mil trabalhadores da Odebrecht entraram em greve, por pagamento de 150 horas referentes à Participação nos Lucros e Resultados - PLR-de 2011. Para o presidente do
Sindicato, teria contribuído para a revolta o tratamento desrespeitoso da Odebrecht para com os trabalhadores (JC, 17/02/2012). Seis dias depois, o movimento foi encerrado, com um acordo firmado entre a empresa e o Sindicato. Para capitalizar esses resultados, o presidente do Sintepav-Pe assim se pronunciou: "venceram os trabalhadores e o bom senso. Mas é importante lembrar que sem a mobilização a empresa não aceitaria rever a sua posição" (DP, 23/02/2012). Esses trabalhadores, no entanto, voltaram a paralisar o trabalho em $18 \mathrm{de}$ junho, reivindicando cumprimento de normas de segurança do trabalho e o pagamento do adicional de periculosidade de $30 \%$. A esses se juntaram 400 trabalhadores do Consórcio Cabeços, revoltados com um acidente que matou um trabalhador na semana anterior. As explosões espontâneas continuavam dando o tom das mobilizações em Suape, com a ação do Sindicato vindo sempre em seguida (DP, 18/06/2012). No dia 19, houve acordo na greve do Consórcio Cabeços, pondo fim à paralisação. Entretanto, a greve na Odebrecht continuou. OSinicon entrou com pedido de dissídio junto ao TRT, mas seguiu negociando. No dia 26 de junho a greve foi encerrada (DP, 26/06/2012).

Em 27 de julho, o Sintepav-Pe assinou acordo com o Sinicon, incluindo: aumento salarial de $10,5 \%$; aumento da cesta básica para $\mathrm{R} \$ 260$; equiparação salarial entre trabalhadores de mesma função, nas diversas empresas. O acordo foi homologado em assembleia, em $1^{\circ}$ de agosto. Entretanto, logo após a homologação, houve revolta, sendo desencadeada uma onda de protestos, com depredações de alojamentos e a paralisação do trabalho (JC, 02/08/2012). Em nota oficial, o Sinicon, argumentou: "diante desta posição, as empresas representadas pelo Sinicon analisam a possibilidade de demissão e outras medidas legais, visto que as negociações já foram encerradas e a convenção já foi assinada junto ao sindicato da categoria” (JC, 02/08/2012). O Sintepav-Pe, em nota oficial, admitiu que foi tomado de surpresa pelo movimento, criticou os "atos de vandalismo, documentos apócrifos ou pessoas encapuzadas" e se disse em defesa dos interesses dos trabalhadores 
(DP, 02/08/2012). Frente às acusações de que a assembleia que votou o acordo havia sido esvaziada, o presidente do Sindicato justificou que teria começado a chover na ocasião, com alguns operários tendo deixado o lugar, acrescentando: "mas quem saiu é como se tivesse assinado uma procuração para quem ficou” (JC, 02/08/2012). Em 6 de agosto, em sessão de conciliação, realizada no MPT, não houve acordo. No dia seguinte, o TRT decretou a greve ilegal (JC, 07/08/2012). O Sintepav-Pe orientou os operários para o retorno ao trabalho e tentou acordo para evitar o desconto dos dias parados. Mas houve revolta na assembleia do dia 8 , que começou com pedras sendo arremessadas contra os diretores do Sindicato, que tiveram que sair às pressas. Dali, a revolta se alastrou, com ônibus e alojamentos sendo depredados. Com a chegada da Polícia, balas de borracha e bombas de efeito moral foram detonadas e prisões efetuadas (JC, 08/08/ 2012). O Sintepav-Pe divulgou nota, condenando a "ação de vândalos", afirmando que realizava uma "assembleia informativa”, para poder cumprir seu "papel institucional" de repassar aos trabalhadores a decisão do TRT. E, na sequência, retorna com o apelo ao discurso desenvolvimentista:

O Sintepav-Pe chama a atenção de toda sociedade pernambucana, em especial o Governo do Estado de Pernambuco, para as consequências de ações isoladas como as que vêm ocorrendo em Suape nos últimos dias. Atitudes como as que se viram hoje afastam novos investimentos, diminuindo assim o número de empregos e consequentemente desaquecendo a economia estadual.

Por fim, assegurou seu apoio à "causa dos seus filiados", defendeu os meios legais de luta e recomendou a volta ao trabalho (JC, 08/08/2012). Nesse contexto, de conflitos explosivos, o Sindicato, que se propunha a se manter em estrito marco institucional e aderente aos termos do discurso estabelecido, se via em apuros. O Sintepav-Pe escolhe um alvo e parte para o ataque: "O PSTU, que é ligado ao Conlutas, tenta dividir a categoria, distribuindo panfletos afirmando que Pernambuco tem um dos piores salários do Brasil e pleiteando um reajuste de 15\%" (declaração do presidente, no JC, 08/08/2012). A resposta do Conlutas veio com a dirigente estadual Cláudia Ribeiro: "O Sintepav-Pe faz acusações falsas, levianas e mentirosas. O que os trabalhadores querem são melhores condições de trabalho. Tudo que aconteceu foi gerado por insatisfações da base, que está jogada em galpões ou em casas onde moram 10, 20 pessoas amontoadas" (JC, 08/08/2012).

No dia 9 do mesmo mês, o retorno ao trabalho foi parcial. Um clima de insegurança se instalou na região, ocupada por policiais. Muitas empresas liberaram os trabalhadores para só retornarem no dia 13. Diante dos acontecimentos, a Secretaria de Articulação Social e Regional foi escalada para atuar no caso (DP, 09/08/2012). No dia 10, tentativas de retorno ao trabalho encontraram a resistência de piquetes. As empresas decidiram flexibilizar as punições (DP, 10/08/2012). Três dias depois, muitos não retornam ao trabalho, em protesto pelo anúncio de desconto dos dias parados e pelo atraso no pagamento do adiantamento quinzenal. Alguns incidentes foram ainda registrados. O Sintepav-Pe procurou se afirmar como condutor das reivindicações, abordando os trabalhadores e orientando-os a baterem o ponto, mas sem retornarem ao trabalho. Em nota, a entidade propõe que só haja retorno quando houver garantias de que as empresas abonarão "todos os dias da paralisação iniciada no último dia $1^{\circ} \mathrm{de}$ agosto" (DP, 13/08/2012). No dia 14, também não houve retorno ao trabalho. Um acordo só veio ocorrer no dia seguinte: o pagamento da quinzena foi liberado e as empresas concordaram em abonar $70 \%$ dos dias parados (DP, 15/08/2012). As atividades foram retomadas no dia 16 de agosto.

Entretanto, com as notícias de que haveria demissões e descontos de parte dos dias parados, retornou um clima de nova paralisação. Novas negociações foram iniciadas, desta vez com a participação de uma comissão de trabalhadores. Houve retorno ao trabalho, mas ficou no ar uma operação "braços cruzados" (DP, 16/08/2012). Um novo impasse se estabeleceu. Os trabalhadores exigiam $100 \%$ de abono dos dias parados. Uma expectativa se criou com a reunião prevista para ocorrer em 
Brasília, com representantes das empresas, das centrais sindicais e do próprio governo. Na pauta, o impasse em Suape. Mas os representantes das centrais sindicais não compareceram, não havendo indicações de solução para os impasses (DP, 17/08/ 2012). Um representante do MTE foi designado para iniciar nova rodada de negociações (DP, 18/08/2012). No dia 20, ainda sem solução, a situação em Suape voltou a ficar tensa com o anúncio de centenas de demissões. No dia seguinte, continuaram as demissões "por justa causa" (DP, 21/08/2012). Ocorreu, no dia 23, a volta ao trabalho (DP, 23/08/2012).

Matéria do JC (26/06/2012) chama a atenção para o que, na visão do órgão, se deve apreender com os acontecimentos: "vinte dias deste mês de agosto abalaram o marco inicial do desenvolvimento econômico de Pernambuco"; "a paralisação agressiva e sem norte [...] escancarou o despreparo do sindicalismo local"; a "escassez de mão de obra qualificada" e os "prazos e orçamentos rígidos para tirar os empreendimentos do papel" "conferem um poder de negociação distorcido para os trabalhadores". Um ator (outsider), ao tentar entrar em cena, para, assim, poder ser reconhecido como portador legítimo de demandas sociais, testa os limites da dimensão justificadora do novo discurso desenvolvimentista (aqui incluído seu componente midiático). Até onde vai o seu alcance?

Os conflitos seguem. Ainda em 2012, uma nova greve geral atingiu os canteiros de obras da Refinaria e da Petroquímica, com duração de 24 dias (de 30 de outubro a 23 de novembro). Novamente o TRT declarou a greve ilegal. Diversos mediadores foram convocados para solucionar os conflitos, entre eles o próprio Brizola Neto, então Ministro do Trabalho, e o presidente nacional da Força Sindical, Paulo Pereira da Silva. Mas a greve só acabou quando o Sinicon e o Sintepav-Pe chegaram a um acordo, com a criação de uma tabela prevendo novos pisos salariais para 32 categorias profissionais (O Estado de São Paulo, 23/11/2012).

Os conflitos em Suape seguem no mesmo ritmo em 2013, mesmo com o início da desmobilização das obras de construção da Refinaria e da Petroquímica. Um outro cenário se anuncia, no en- tanto, quanto mais tal desmobilização avança, cuja previsão é que se estenda até a virada para 2014.

\section{CONSIDERAÇÕES FINAIS}

Neste artigo, nos detivemos sobre conflitos envolvendo os peões eas empresas das grandes obras de Suape. Vimos que esses conflitos se desdobram e se articulam sob focos diversos, opondo: peões "forasteiros" e aqueles de origem local; trabalhadores diretos e terceirizados; trabalhadores e forças policiais; trabalhadores e Sindicato; militantes da Conlutas e do Sindicato; comunidades locais e gestores públicos e privados de Suape, entre outros.

Pudemos notar que, não obstante a ausência de uma organização sindical capaz de captar, sistematizar e expressar os interesses e demandas coletivas dos trabalhadores, estes se mobilizaram e obtiveram conquistas relacionadas a salário, vale refeição, horas extras, condições de alojamento, abono de dias parados, reconhecimento e estabilidade para comissões de trabalhadores, entre outras.

Para além disso, percebemos que, entrando em cena, sob formas explosivas e inesperadas, os peões de Suape e suas condições de existência e trabalho se tornaram visíveis para a sociedade. Que questões, com isso, colocam para o novo discurso e agenda desenvolvimentista? Vimos o quanto elementos das críticas ao projeto Suape foram sendo incorporados, de algum modo, nos discursos e práticas dos atores estratégicos ali implicados. Não à toa, em agosto de 2011, no auge das mobilizações em Suape, o governador assim se pronunciou:

Cresce na nossa consciência a importância de planejar a expansão dessa região. Não queremos repetir desigualdades que se arrastam por quatro séculos de história. Porque de desigualdade esse território de Suape entende. São marcas muito profundas, que começaram com a exploração dos índios e dos escravos, e não poderão se repetir nesse novo ciclo de desenvolvimento (JC, 12/08/2011).

Em que medida o discurso estabelecido do novo desenvolvimentismo, diante dessa dimensão que se visibiliza com os conflitos, incorpora algo da crítica como reconhecimento ou tão somente como 
justificação? Por outro lado, até onde os trabalhadores têm sido capazes de se fazer reconhecer? ${ }^{21} \mathrm{Com}$ os conflitos aqui sumarizados, sobressai o fato de que aqueles conseguiram, protagonizando acontecimentos espetaculares, se tornar visíveis. Ao mesmo tempo, ficou evidenciado que a mediação sindical, ao contrário de se constituir como um novo agenciamento social, no sentido de Sader (1988), não tem sido capaz de processar tais demandas e de se converter em canal de elaboração de uma nova matriz prático-discursiva. Conversas com sindicalistas atuantes em Suape e as evidências trazidas com o desenrolar dos conflitos e negociações nos indicam o quanto o sindicalismo na região está longe de cumprir esse papel, o que, para tanto, requereria um outro patamar de elaboração estratégica de suas linhas de ação, de modo a contemplar, entre outros aspectos: consolidação de sua capacidade de representação diante dos trabalhadores; enraizamento e projeção como ator influente no arranjo político e institucional local; articulação em perspectiva de cadeias produtivas, de modo a compor ações nacionais e internacionais referidas às conexões de Suape com a economia nacional e global; articulação em uma perspectiva de ação mais ampla, reportada ao debate sobre os rumos do desenvolvimento do país. A abordagem da experiência sindical em Suape, a partir das dimensões propostas acima, certamente, pode vir a ser bastante enriquecida quando posta vis-à-vis experiências outras, de relevância internacional, assim como nacional. Neste caso, sobressai o caso do ABC Paulista (Véras de Oliveira, 2011; Ramalho e Rodrigues, neste dossiê).

Na ausência de uma atuação sindical mais consistente, os trabalhadores de Suape, se têm conseguido dar visibilidade a si e às suas demandas, não necessariamente têm sido capazes de se fazer reconhecidos (na sua condição de agentes e portadores de demandas) como parte do empreendimento desenvolvimentista. Voltamos, assim, ao tema do jogo de tensões entre as razões econômicas (referi-

${ }^{21}$ Todo o processo da constituição de mesas de negociações, com a mediação do MPT, as dificuldades de representação efetiva por parte do Sintepav-Pe e da comissão dos trabalhadores, as ameaças empresariais, as sentenças do TRT, que aqui vimos, ganha relevância quanto a isso. das a noções tais como eficácia, competitividade, crescimento, acumulação) e sociais (reportadas à equidade, redistribuição, proteção social, participação e controle social), enquanto parâmetros para discutirmos os termos e possibilidades do novo discurso/agenda desenvolvimentista. Os conflitos do trabalho, no entanto, continuam; as disputas de sentidos, também. Migrando desses canteiros a outros (seja para se integrar a construção da planta da Fiat, que já se inicia, ou para atuar em outras grandes obras país afora) e daí aos novos empreendimentos, na medida em que vão entrando em funcionamento (estaleiros, refinaria, petroquímica, siderúrgica, indústria de alimentos e bebidas etc.), as reconversões identitárias, as disputas sindicais e os conflitos do trabalho continuarão ganhando novos impulsos e seguirão impactando as dinâmicas econômicas, sociais e políticas na região. A questão que fica se refere à capacidade dos trabalhadores e suas representações sindicais se afirmarem como protagonistas na construção de um novo padrão de relações de trabalho e de uma perspectiva de desenvolvimento que venha a ter nos elementos da equidade social e da sustentabilidade ambiental, aspectos tão estratégicos como o da eficiência econômica. Isso implicará tensionar e levar ao limite os termos atuais do padrão de desenvolvimento embalado na nova edição, em Pernambuco e no Brasil, da agenda e discurso desenvolvimentistas.

Recebido para publicação em 21 de abril de 2013 Aceito em 10 de junho de 2013

\section{REFERÊNCIAS}

ARAÚJO, A.; VÉRAS DE OLIVEIRA, R. El sindicalismo brasileño em la Era de Lula. Trabajo. México, v. 5, n. 08, p. 83-112, 2011.

BATISTA JR., P. N. Desenvolvimento "light”? Folha de São Paulo, 25/01/2007.

BOLTANSKI, L.; CHIAPELLO, E. O novo capitalismo. São Paulo: WMF Martins Fontes.

BOSCHI, R. Introdução: instituições, trajetórias e desenvolvimento - uma discussão a partir da América Latina. In: BOSCHI, R. (Org.). Variedades de capitalismo, política e desenvolvimento na América Latina. Belo Horizonte: Editora UFMG, 2011.

BRASIL. Programa de Aceleração do Crescimento: balanço 4 anos (2007-2010). Brasília: Ministério do Planejamento, 2010. 
. PAC 2. Brasília: Ministério do Planejamento, 2012.

BRESSER-PEREIRA, L. C. Desenvolvimento e crise no Brasil: história, economia e política de Getúlio Vargas a

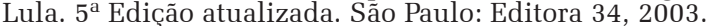

O novo desenvolvimentismo e a ortodoxia convencional. São Paulo em Perspectiva, São Paulo, Fundação Seade, v. 20, n. 3, p. 5-24, jul./set., 2006.

CARNEIRO, R. Um intelectual em seu labirinto. Carta Maior 03/04/2012. Disponível em: http://www.cartamaior.com.br/ templates/materiaMostrar.cfm?materia id=19890. Consulta em 15/05/2012.

CAVALCANTI, C. Desenvolvimento e meio ambiente: o conflito do Complexo Industrial-Portuário de Suape, Pernambuco. Brasília. IV ENCONTRO NACIONAL DA ANPPAS, 4 a 6/06/2008.

CAVALCANTI, H.: ROCHA, D. Nordestes emergentes: uma "expediç̃o fotográfica" no "admirável mundo novo" - o Complexo Industrial Portuário de Suape. Recife: Fundaj, abril, 2013.

COCKELL, F. F.; PERTICARRARI, D. Contratos de boca: a institucionalização da precariedade na construção civil. $C a$ derno CRH, Salvador, v. 23, n. 60, set./dez., p. 633-653. 2010.

DINIZ, E. O contexto internacional e a retomada do debate sobre desenvolvimento no Brasil contemporâneo (2000/ 2010). Dados, Rio de Janeiro, v. 54, n. 4, p. 493 a 531, 2011.

DRAIBE S. M.; RIESCO, M. Estados de Bem-Estar Social e estratégias de desenvolvimento na América Latina; um novo desenvolvimentismo em gestação? Sociologias, Porto Alegre, v. 13, n. 27, maio./ago., 2011, p. 220-254.

FIORI, J. L. O “desenvolvimentismo de esquerda". Carta Maior, 03/03/2012. Disponível em: http:// www.outraspalavras.net/2012/03/02/o$\%$ E2\%80\%9Cdesenvolvimentismo-de-esquerda/). Consulta em 15/05/2012.

. Desenvolvimentismo e "dependência". Carta Maior, 03/04/2012b. Disponível em: http://www.controversia.com.br/ index.php?act=textos\&id=12386. Consulta em 15/05/2012.

FRASER, N. From redistribution to recognition? Dilemmas of justice in a "Postsocialist" Age. In: OLSON, K. (Ed.). Adding insult to injury: Nancy Fraser debates her critics. London: Verso, 2008

GUEDES, A. D. O Trecho, as mães e os papéis movimentos e durações no Norte de Goiás. (Tese de Doutorado) Museu Nacional/UFRJ, 2011.

IBGE. Censo. Brasília. Anos Diversos.

. Pesquisa Mensal de Emprego. Brasília. Anos Diversos.

IVO, A. B. L. O paradigma do desenvolvimento: do mito fundador ao novo desenvolvimento. Caderno CRH, Salvador, v. 25, n. 65, p.187 -210, maio./ago. 2012.

KERSTENETZKY, C. L. Welfare State e desenvolvimento. Dados, Rio de Janeiro, v. 54, n. 1, p. 129-156, outubro, 2011.

KREIN, D. et al. Trabalho no governo Lula: avanços e contradições. Revista da Abet, v. 11, n. 2, jul-dez, 2011.

LEBRET, L. J. Estudo sobre desenvolvimento e implantação de indústrias, interessando a Pernambuco e ao Nordeste. Recife: CDEP, 1955.

LIMA, J. P.; KATZ, F. A economia de Pernambuco: perda de dinamismo e a necessidade de buscar caminhos possíveis. Cadernos de Estudos Sociais, Recife, v. 9, n. 1, jan./ jun. 1993, p. 80-104.

MONTEIRO, A. L. Refinaria Abreu e Lima em Suape: perspectivas para o desenvolvimento econômico regional. 205 p. Tese (Doutorado em Geografia), UFPE, 2011.

MOUTINHO, L. M. et al. Impactos dos grandes projetos federais na economia de Pernambuco e proposições de políticas. In: Análise do mapeamento e das políticas para Arranjos Produtivos Locais no Norte, Nordeste e Mato Grosso e dos impactos dos grandes projetos federais no Nordeste. Nota Técnica 13, BNDES, 2011.

MTE/CAGED. CADASTRO GERAL DE EMPREGADOS E DESEMPREGADOS CAGED http://portal.mte.gov.br/ caged/ Acesso em março de 2013. Brasília, 2003 a 2013.

NAVILLE, P. Essai sur la qualification du travail. 1ª Édition [1956]. Paris: Syllepse (Editions), 2012.

OLIVEIRA, F. Elegia para uma re(li)gião. Rio de Janeiro: Paz e Terra, 1981.

PÊGO, B.; CAMPOS NETO, C. O PAC e o setor elétrico: desafios para o abastecimento do mercado brasileiro (20072010). Texto para Discussão, Brasília: Ipea, n. 1329, 2008.

PÉREZ, M.; GONCALVES, C. Desenvolvimento e conflito territorial - primeiras reflexões sobre as comunidades atingidas pelo Complexo Industrial Portuário de Suape-Pe, Brasil. Revista de Geografia, Recife, v. 29, n. 2, p. 166-179, 2012.

POCHMANN, M. Novo desenvolvimentismo como resposta à crise global. In: CASTRO, D.; MELO, J. M. (Orgs.), Panorama da comunicação e das telecomunicações no Brasil, 2011-2012: Indicadores. Brasília: Ipea, 2012.

RAINHO, Luís Flávio. Os peões do grande ABC. Petrópolis: Vozes, 1980

RAMALHO, J. R.; FORTES, A. (Orgs.). Desenvolvimento, trabalho e cidadania: Baixada e Sul Fluminense. Rio de Janeiro: Sete Letras, 2012.

REVISTA GRANDES CONSTRUCÕES. Petrobras fecha contratos para obras na refinaria Abreu e Lima. N. 01, 02 03/2010 (http://www.grandesconstrucoes.com.br/br/ index.php?option $=$ com conteudo\&task=viewMateria\&id=44). Acesso em março de $\overline{2} 013$.

RIDENTI, M. Desenvolvimentismo: o retorno. Revista Espaço Acadêmico. Maringá, n. 92, jan-2009. http:// www.espacoacademico.com.br/092/92ridenti.pdf. Acesso em outubro de 2011.

ROCHA, D. A dialética do local e do global: os atores e as metamorfoses dos lugares no litoral do cabo de Santo Agostinho. (Dissertação) UFPE, 2000.

RODRIGUES, Victor. O. Para não dizer que não falei das flores: as lutas dos trabalhadores na Construção Civil no Complexo Industrial e Portuário de Suape (PE). (Dissertação) PPGS/UFPE, 2012.

SADER, E. Quando novos personagens entram em cena: experiências e lutas dos trabalhadores da Grande São Paulo, 1970-1980. Rio de Janeiro: Paz e Terra, 1988.

SANTOS, V. Entrevista concedida ao IHU On-Line, 24/04/ 2012 (www.ihu.unisinos.br/entrevistas/508579-suapeum-desafio-para-pernambuco-entrevista-especial-comvaldeci-monteiro-dos-santos). Acesso em janeiro de 2013. SICSÚ, J. et al. Por que novo-desenvolvimentismo? Revista de Economia Política. São Leopoldo, v. 27, n. 4, p. 507-524 out.-dez., 2007.

SOARES JÚNIOR, B. R.; MARTINS, W. O "mito do desenvolvimento econômico" e a formação profissional no Litoral Sul de Pernambuco. Revista do ISEP, Recife, 2010. http: /www.isepnet.com.br/website/revista/Revista ISEP 01/ artigos_revista.pdf. Acesso em outubro de 2011.

SUAPE/GOVERNO PERNAMBUCO. PAC/Complexo Suape: Relatório - Março de 2010. Disponível em: http:// www.suape.pe.gov.br/pdf/relatorioObraSuapeMarco2010.pdf. Acesso em 21 de junho de 2012.

VÉRAS DE OLIVEIRA, R. Sindicalismo e democracia no Brasil - do novo sindicalismo ao sindicato cidadão. São Paulo: Annablume, 2011. 


\section{SUAPE UNDER CONSTRUCTION, UNSKILLED LABORERS IN STRUGGLE: new development and labor conflicts}

\author{
Roberto Véras de Oliveira
}

Taking the labor and conflicts point of view, this article discusses the emergence of a new agenda for development in Brazil. Its focus is the construction worker protests and strikes at two of the Suape Port Industrial Complex's main sites, the Abreu e Lima Refinery and the Suape Petrochemical Plant, in 2011 and 2012. Through the use of this approach we intend to comprehend the processes touched off by the conflicts, mediations, and negotiations, as well as what has been at stake with workers' demands and also union, management and government discourse and practices. We ask ourselves if these mobilizations, besides giving them immediate gains, have given workers recognition as legitimate agents of social demands. We also ask to what degree such demands have become not only a target of public outcry but also a way of problematizing the terms that give sustenance to the new development discourse.

KEY WORDS: Development. Labor. Unionism. Civil construction. Suape.

\section{LA CONSTRUCTION DE SUAPE, DES OUVRIERS QUI LUTTENT: le nouveau développement et les conflits du travail}

\author{
Roberto Véras de Oliveira
}

Cet article examine l'émergence d'un nouveau programme de développement au Brésil dans l'optique du travail et de ses conflits. L'accent est mis sur les émeutes et les grèves des ouvriers qui travaillent dans la construction de deux des principales entreprises du Complexe Industriel Portuaire de Suape, la Raffinerie Abreu et Lima et l'entreprise pétrochimique Suape, au cours des années 2011 et 2012. Cette approche se veut d'analyser les processus déclenchés par les conflits, les médiations et les négociations et ce qui a été remis en question, en parallèle aux demandes des travailleurs ainsi que les discours et les pratiques des gouvernements, des entreprises et des syndicats. Nous nous demandons si ces mobilisations ont permis, au-delà des gains immédiats obtenus par les travailleurs, que ceux-ci soient reconnus comme les porteurs légitimes des revendications sociales. Et dans quelle mesure de telles revendications ne sont pas seulement l'objet d'une dénonciation publique mais représentent aussi une manière de remettre en cause les termes du nouveau discours sur le développement.

Mots-CLÉs: Développement. Travail. Syndicalisme. Construction civile. Suape.

Roberto Véras de Oliveira - Doutor em Sociologia. Professor do Departamento de Ciências Sociais da Universidade Federal da Paraíba (UFPB) e membro do Programa de Pós-Graduação em Sociologia da UFPB (PPGS) e do Programa de Pós-Graduação em Ciências Sociais da Universidade Federal de Campina Grande (PPGCS/UFCG). Pesquisador do CNPQ. Preferencialmente, orienta seus estudos e pesquisas para os campos da Sociologia do Trabalho e da Sociologia Política. Tem concentrado sua atenção (na forma de publicações, orientações e participação em eventos) sobre temas como sindicalismo, relações de trabalho, qualificação profissional, políticas públicas de trabalho, emprego e renda, economia solidária, diálogo social, cidadania, entre outros. É autor e coautor de várias publicações em revistas científicas e livros. Entre estes, Sindicalismo e Democracia no Brasil - do novo sindicalismo ao sindicato cidadão. São Paulo: Annablume, 2011. 